\title{
Drought and frost contribute to abrupt growth decreases before tree mortality in nine temperate tree species
}

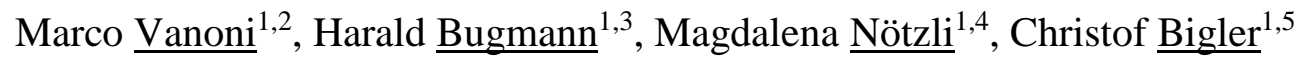 \\ ${ }^{1}$ Forest Ecology, Institute of Terrestrial Ecosystems, Department of Environmental Systems \\ Science, ETH Zurich, Universitätstrasse 16, CH-8092 Zurich, Switzerland \\ 2 marco.vanoni@usys.ethz.ch; marco.vanoni@gmail.com \\ ${ }^{3}$ harald.bugmann@env.ethz.ch \\ ${ }^{4}$ magdalena.noetzli@usys.ethz.ch \\ ${ }^{5}$ christof.bigler@env.ethz.ch
}

\section{Corresponding Author}

Marco Vanoni

telephone +41446328257

fax: +41446331122

email:marco.vanoni@usys.ethz.ch; marco.vanoni@gmail.com 


\begin{abstract}
Tree mortality as a crucial element of natural forest dynamics is still a poorly understood process. Abrupt growth decreases are known to occur several years or decades before complete cessation of growth. Hence, identifying and linking these growth decreases to potential inciting factors such as drought and frost will improve our understanding of mortality processes. We analyzed nine Central European tree species including six coniferous species (Abies alba, Picea abies, Larix decidua, Pinus sylvestris, Pinus cembra, Pinus montana) and three broadleaved species (Fagus sylvatica, Quercus spp., Acer pseudoplatanus). Tree-ring data from 848 standing dead trees from 14 forest reserves all over Switzerland were sampled. We applied distributed lag non-linear models to relate abrupt growth decreases to drought and frost. The results indicate for many species that both drought and frost have a moderate to major impact on abrupt growth decreases prior to tree death. While late frost in spring may instantaneously result in sustained abrupt growth decreases in most species except Scots pine and mountain pine, severe drought over several months in spring may either show an immediate negative impact on growth, such as in beech, or feature negative reactions that are lagged by several years, such as in oak and Scots pine. Thus, extreme climatic conditions have an essential influence on abrupt growth decreases that finally result in tree death, although variability of the reactions within and among species is high.
\end{abstract}

\title{
Keywords
}

distributed lag non-linear models, lagged effects, tree rings, breakpoint analysis 


\section{Introduction}

Forest dynamics result from a wide range of ecological processes, with tree mortality being a key element (Franklin et al., 1987). Complex interactions between growth, competition and disturbances lead to high temporal and spatial variability of mortality processes, and therefore tree mortality continues to be recognized as one of the most crucial but least understood processes of forest dynamics (Adame et al., 2010). Natural tree mortality may be partitioned into "regular" (non-catastrophic) and "irregular" (catastrophic) mortality (Monserud, 1976; Hawkes, 2000; Alenius et al., 2003). The description and partitioning of different mortality modes is necessary to identify the factors that are involved and to enable mechanistic modelling approaches (Holzwarth et al., 2013). A general conceptual model to describe and understand the processes driving regular mortality, also described as background mortality (van Mantgem et al., 2009), is the decline disease theory, which differentiates predisposing, inciting, and contributing factors (Manion, 1991). These three sets of factors are assumed to affect a tree's vigor along time and may ultimately result in tree death. Long-term factors such as climate, competition or soil nutrients are typically considered as predisposing factors (Allen et al., 2010). Inciting factors act in the short-term and comprise a broad suite of processes, with drought and frost being two of the most prominent climatic factors (CharraVaskou et al., 2011). Further abiotic and biotic inciting factors that generally have a minor influence are - among others - stem breakage (e.g., caused by wind, ice or massive snowfall), defoliating insects, or pathogens (Anderegg et al., 2015a; Haavik et al., 2015). Contributing factors such as bark beetles or canker fungi may interact with these other factors, ultimately leading to tree death, but they do not necessarily induce tree death when acting in isolation (Allen et al., 2010).

Drought has become an increasingly important driver of forest decline and tree mortality across the world (Allen et al., 2010; Clark et al., 2016). The current debate related to the 
mechanisms of drought-induced tree death emphasizes the relative importance of hydraulic failure (Anderegg et al., 2012) versus carbon starvation due to water stress (Sala et al., 2010; Hartmann, 2011). In general, species-specific responses to drought are strongly affected by stand history and the legacies of past disturbances, which thus can be viewed as predisposing factors (Bond-Lamberty et al., 2014; Anderegg et al., 2015b). Although there is substantial tree-to-tree variation in drought avoidance and drought tolerance traits (Anderegg and HilleRisLambers, 2016), recent studies have suggested that severe drought may induce multiyear growth declines (Berdanier and Clark, 2016; Panayotov et al., 2016) and partly lagged abrupt growth decreases (Vanoni et al., 2016).

The cellular mechanisms of frost damage in trees are generally thought to be similar to those of drought, but less is known about the effective physiological processes (Charrier et al., 2015). Frost damage may be caused either be intracellular freezing of the living cell contents or by extracellular freezing that affects cells by dehydration (Kozlowski et al., 1991). In most cases, freezing injury is supposed to be indirectly caused by dehydration, while freezing tolerance depends mostly on the capacity of the protoplasm to survive such dehydration (Kozlowski et al., 1991). Hence, frost events can have similar effects as drought and may lead to instantaneous growth reductions (Dittmar et al., 2006) or a visible distortion of xylem cells commonly described as frost rings (Schweingruber, 1996). There is an ongoing discussion about the influence of various types of frost. While trees in the dormant season are principally adapted to freezing (Perry, 1971), extremely low temperatures (i.e., deep frost) during this time were found to have a considerable effect on growth (Lebourgeois, 2007). However, major frost damages are normally caused by late frost events (i.e., in the early growing period), when new shoots are being produced and leaves and needles unfold (Cannell and Smith, 1986; Kozlowski et al., 1991). There is a trade-off of early versus late budburst between the risk of damage by late frost and the photosynthetic gain (Morecroft and Roberts, 
1999; Herbst et al., 2015). Among and within many species, there is a high variability in the timing of budburst and leaf unfolding (Vitasse et al., 2009), which contributes to the strong diversification of frost tolerance.

In this study, we aim at quantifying the effects of drought and frost as two main inciting factors on tree mortality, which we test for nine Central European tree species along a wide range of environmental conditions, i.e. from warm-dry lowland to cold-wet high-elevation conditions. A statistical framework is applied to identify abrupt growth reductions and quantify the effects of drought and frost on growth reductions that eventually result in tree death. We furthermore provide an overview of potentially complementing factors that incite tree mortality in multiple species. Specifically, we hypothesize that (i) the importance of drought versus frost as inciting factors of abrupt growth decreases prior to tree death varies across tree species; (ii) the effects of drought and frost on abrupt growth decreases change along the environmental gradient, and (iii) abrupt growth reductions due to frost are more immediate than those that are due to drought. 


\section{Material and Methods}

\subsection{Species}

Nine of the most important Central European species were considered in this study, including six coniferous species (silver fir, Abies alba Mill.; Norway spruce, Picea abies [L.] Karst; European larch, Larix decidua Mill.; Scots pine, Pinus sylvestris L.; Swiss stone pine, Pinus cembra L.; upright mountain pine, Pinus mugo Turra ssp. uncinata, also described as Pinus montana Mill.), and three broadleaved species (European beech, Fagus sylvatica L.; oak, Quercus spp., including sessile oak (Q. robur L.) and pedunculate oak (Q. petraea [Matt.] Liebl.); sycamore maple, Acer pseudoplatanus L.). For simplicity the species are hereafter referred to as fir, spruce, larch, Scots pine, stone pine, mountain pine, beech, oak and maple. We denote sessile and pedunculate oak in our analysis as "oak" ( $Q$. spp.) because (i) based on wood anatomical characteristics, no clear differentiation between the two oak species is feasible, (ii) leaves and acorns on the dead trees were missing that would have allowed distinction between the two species, and (iii) both species had been recorded as $Q$. robur in the inventories of the permanent plots in the forest reserves where this study took place.

The ecophysiological traits of the nine species cover a broad spectrum, and they overlap to some extent (Ellenberg and Leuschner, 2010). With respect to their tolerances to drought and late frosts, a simplistic classification can be made: Scots pine, stone pine, mountain pine and oak (with $Q$. petraea being less sensitive than $Q$. robur) are least sensitive to drought; fir and maple feature medium sensitivity; larch and beech have large sensitivity; and spruce is the most vulnerable species to drought (Tab 4-11 in Ellenberg and Leuschner, 2010). With respect to late frost, Scots pine, stone pine and mountain pine are least sensitive, while fir and beech are most sensitive; the other species are considered as having medium frost sensitivity (Ellenberg and Leuschner, 2010; Lebourgeois et al., 2010; Charrier et al., 2013). 


\subsection{Study area}

We used tree-ring data from 14 reserves of the Swiss network of strict forest reserves (Table 1, Fig. 1) that had been established between 1933 and 1986 (Brang et al., 2011). Two of the forests are characterized as primeval forests without any human impact for several centuries (i.e., Derborence and Scatlè), while some were managed up to the designation as a reserve. All reserves had been unmanaged for at least the last few decades (i.e., neither were trees cut nor logs removed) and are currently in various development stages, all shifting towards natural conditions (Brang et al., 2011). Permanent plots of variable size up to 3 hectares (ha) had been installed in the reserves, where every tree above a diameter at breast height (DBH) of $4 \mathrm{~cm}$ was tagged. At intervals of 5-10 years, several variables such as species, DBH and tree status (dead/alive) were recorded repeatedly by collaborators of ETH Zurich and the Swiss Federal Institute for Forest, Snow and Landscape Research WSL (Birmensdorf).

Table 1: Characteristics of the forest reserves. Species: fir (Abies alba), spruce (Picea abies), larch (Larix decidua), Scots pine (Pinus sylvestris), stone pine (Pinus cembra), mountain pine (Pinus montana), beech (Fagus sylvatica), oak (Quercus spp.) and maple (Acer pseudoplatanus). Temperature and precipitation means refer to the period 1932 to 2011.

\begin{tabular}{|c|c|c|c|c|c|c|}
\hline $\begin{array}{l}\text { Forest } \\
\text { reserve } \\
\text { code }\end{array}$ & Site & Species & $\begin{array}{l}\text { Coordinates } \\
\text { WGS84 }\end{array}$ & $\begin{array}{l}\text { Mean } \\
\text { elevation } \\
\text { [m a.s.1.] }\end{array}$ & $\begin{array}{l}\text { Annual mean } \\
\text { temperature } \\
{\left[{ }^{\circ} \mathrm{C}\right]} \\
\end{array}$ & $\begin{array}{l}\text { Annual mean } \\
\text { precipitation } \\
{[\mathrm{mm}]}\end{array}$ \\
\hline 01 & Aletschwald & Larch, stone pine & $\begin{array}{l}46^{\circ} 23^{\prime} 21^{\prime \prime} \mathrm{N} \\
8^{\circ} 011^{\prime} 25^{\prime \prime} \mathrm{E}\end{array}$ & 2000 & 1.49 & 1396 \\
\hline 04 & Pfynwald & Scots pine & $\begin{array}{l}46^{\circ} 17^{\prime} 37^{\prime \prime} \mathrm{N} \\
7^{\circ} 33^{\prime} 52^{\prime \prime} \mathrm{E}\end{array}$ & 570 & 9.64 & 670 \\
\hline 05 & Derborence & Larch & $\begin{array}{l}46^{\circ} 16^{\prime} 38^{\prime \prime} \mathrm{N} \\
7^{\circ} 13^{\prime} 05^{\prime \prime} \mathrm{E}\end{array}$ & 1500 & 4.59 & 1401 \\
\hline 07 & Girstel & Maple & $\begin{array}{l}47^{\circ} 18^{\prime} 44^{\prime \prime} \mathrm{N} \\
8^{\circ} 30^{\prime} 07^{\prime \prime} \mathrm{E}\end{array}$ & 700 & 7.51 & 1304 \\
\hline 11 & Weidwald & Beech, oak & $\begin{array}{l}47^{\circ} 24^{\prime} 533^{\prime \prime} \mathrm{N} \\
7^{\circ} 59^{\prime} 47^{\prime \prime} \mathrm{E}\end{array}$ & 550 & 8.32 & 1163 \\
\hline 12 & Scatlè & Spruce & $\begin{array}{l}46^{\circ} 47^{\prime} 26^{\prime \prime} \mathrm{N} \\
9^{\circ} 02^{\prime} 54^{\prime \prime} \mathrm{E}\end{array}$ & 1600 & 3.29 & 1582 \\
\hline 14 & Bois de Chênes & $\begin{array}{l}\text { Spruce, beech, } \\
\text { oak }\end{array}$ & $\begin{array}{l}46^{\circ} 26^{\prime} 08^{\prime \prime} \mathrm{N} \\
6^{\circ} 14^{\prime} 20^{\prime \prime} \mathrm{E}\end{array}$ & 530 & 9.59 & 1042 \\
\hline 20 & Vorm Stein & Oak & $\begin{array}{l}47^{\circ} 33^{\prime} 10^{\prime \prime} \mathrm{N} \\
8^{\circ} 27^{\prime} 13^{\prime \prime} \mathrm{E}\end{array}$ & 540 & 8.65 & 1118 \\
\hline 21 & $\begin{array}{l}\text { Tariche Bois } \\
\text { Banal }\end{array}$ & Maple & $\begin{array}{l}47^{\circ} 20^{\prime} 12^{\prime \prime} \mathrm{N} \\
7^{\circ} 09^{\prime} 01^{\prime \prime} \mathrm{E}\end{array}$ & 560 & 8.67 & 1108 \\
\hline 22 & Tariche Haute & Fir, beech & $47^{\circ} 20^{\prime} 08^{\prime \prime} \mathrm{N}$ & 750 & 7.76 & 1228 \\
\hline
\end{tabular}




\begin{tabular}{|c|c|c|c|c|c|c|}
\hline & Côte & & 709'43'”E & & & \\
\hline 24 & Leihubel & Fir, spruce & $\begin{array}{l}46^{\circ} 52^{\prime} 08^{\prime \prime} \mathrm{N} \\
8^{\circ} 08^{\prime} 35^{\prime \prime} \mathrm{E}\end{array}$ & 1200 & 5.96 & 1711 \\
\hline 30 & Strassberg & Oak & $\begin{array}{l}47^{\circ} 31^{\prime} 55^{\prime \prime} \mathrm{N} \\
8^{\circ} 29^{\prime} 45^{\prime \prime} \mathrm{E}\end{array}$ & 470 & 8.83 & 1068 \\
\hline 33 & Nationalpark & $\begin{array}{l}\text { Mountain pine, } \\
\text { stone pine }\end{array}$ & $\begin{array}{l}46^{\circ} 12^{\prime} 33^{\prime \prime} \mathrm{N} \\
10^{\circ} 12^{\prime} 37^{\prime \prime} \mathrm{E}\end{array}$ & 2000 & 1.76 & 930 \\
\hline 39 & Combe Biosse & Fir, maple & $\begin{array}{l}47^{\circ} 06^{\prime} 21^{\prime \prime} \mathrm{N} \\
7^{\circ} 00^{\prime} 38^{\prime \prime} \mathrm{E}\end{array}$ & 1250 & 5.88 & 1363 \\
\hline
\end{tabular}

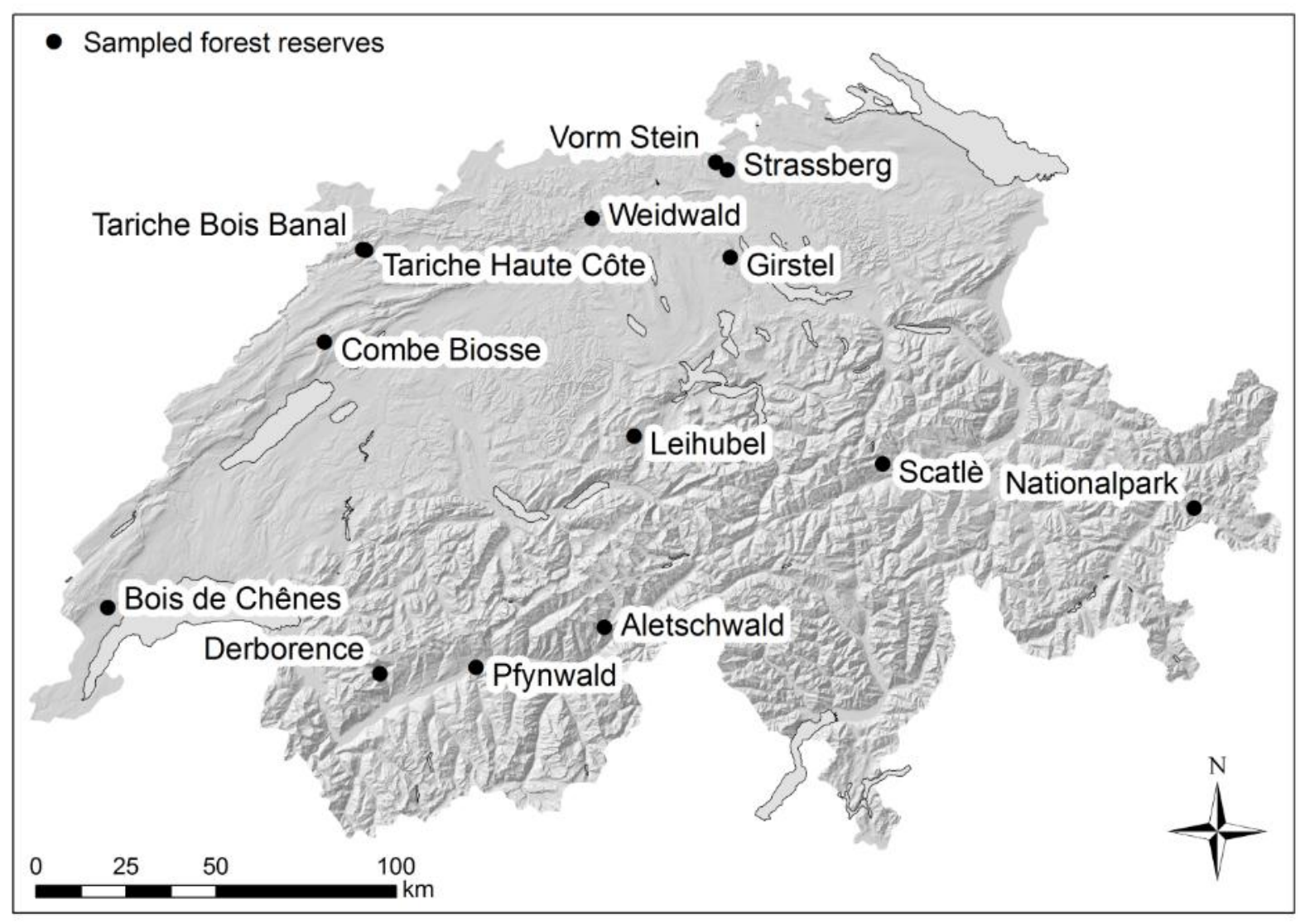

Fig. 1: Location of the selected forest reserves in Switzerland.

The sites are characterized by distinct climate regimes (Table 1), ranging from rather dry and warm conditions (Pfynwald, $9.64^{\circ} \mathrm{C}$ annual mean temperature, $670 \mathrm{~mm}$ annual mean precipitation) across moist-cool conditions (Leihubel, $5.96^{\circ} \mathrm{C}, 1711 \mathrm{~mm}$ ) to medium moist but cold conditions (Aletschwald, $1.49^{\circ} \mathrm{C}, 1396 \mathrm{~mm}$ ). A detailed description of the sites including the dominant tree species is provided in Appendix A.1. 


\subsection{Field sampling and laboratory methods}

Sampling of most species in thirteen reserves took place in 2013 (Vanoni et al., 2016) and 2014. Scots pine in Pfynwald had been sampled in 2008 (Rohner, 2008) and mountain pine in Nationalpark in 2009 (Bigler, 2016). We selected a representative sample of trees based on the DBH distribution of the reserves, including trees with a $\mathrm{DBH}>4 \mathrm{~cm}(>8 \mathrm{~cm}$ for oak in Weidwald, $>10 \mathrm{~cm}$ for Scots pine in Pfynwald and mountain pine in Nationalpark due to a slightly different sampling design), covering a wide range of size and age classes. A variable number of standing dead trees (i.e., snags) was sampled, resulting in a total number of 848 trees, separated into 22 sampling groups (Table 2). Trees were classified as "dead" if green leaves and needles, respectively, were lacking. We only selected trees without any apparent scars or wounds resulting from disturbances such as rock fall, wind or snow breakage, avalanches or fire, because our field sampling was focusing on background mortality (van Mantgem et al., 2009). Two increment cores were extracted from every tree at a height of $1 \mathrm{~m}$ $(0.84 \pm 0.24 \mathrm{~m}$ for mountain pine; Bigler, 2016) parallel to the contour lines to reduce effects of eccentricity caused by compression and tension wood, respectively.

Table 2: Tree-ring characteristics of the 22 sampling groups.

\begin{tabular}{lllll}
\hline Sampling group & Site & $\begin{array}{l}\text { Number } \\
\text { of trees }\end{array}$ & $\begin{array}{l}\text { Average life span } \pm \\
\text { SD }^{\mathrm{b}}(\text { years })\end{array}$ & $\begin{array}{l}\text { Average growth rate } \pm \\
\text { SD }^{\mathrm{b}}(\mathrm{mm} / \text { year }\end{array}$ \\
\hline Spruce 12 & Scatlè & 35 & $168.3 \pm 70.9$ & $0.76 \pm 0.30$ \\
Spruce 14 & Bois de Chênes & 35 & $60.9 \pm 9.8$ & $1.15 \pm 0.33$ \\
Spruce 24 & Leihubel & 29 & $128.9 \pm 63.6$ & $0.78 \pm 0.35$ \\
Fir 22 & Tariche Haute Côte & 36 & $88.8 \pm 15.0$ & $0.84 \pm 0.50$ \\
Fir 24 & Leihubel & 38 & $82.1 \pm 38.8$ & $0.76 \pm 0.27$ \\
Fir 39 & Combe Biosse & 44 & $92.9 \pm 28.1$ & $0.88 \pm 0.46$ \\
Oak 11 & Weidwald & 20 & $134.9 \pm 14.6$ & $0.61 \pm 0.16$ \\
Oak 14 & Bois de Chênes & 50 & $119.2 \pm 34.2$ & $0.80 \pm 0.21$ \\
Oak 20 & Vorm Stein & 50 & $93.0 \pm 21.2$ & $0.81 \pm 0.21$ \\
Oak 30 & Strassberg & 47 & $78.4 \pm 23.8$ & $1.16 \pm 0.26$ \\
Beech 11 & Weidwald & 47 & $120.6 \pm 18.7$ & $0.85 \pm 0.31$ \\
Beech 14 & Bois de Chênes & 44 & $75.1 \pm 15.5$ & $1.14 \pm 0.60$ \\
Beech 22 & Tariche Haute Côte & 44 & $121.6 \pm 27.1$ & $0.86 \pm 0.22$ \\
Stone pine 01 & Aletschwald & 24 & $133.0 \pm 88.2$ & $0.55 \pm 0.27$ \\
Stone pine 33 & Nationalpark & 15 & $110.4 \pm 31.1$ & $0.66 \pm 0.19$ \\
Larch 01 & Aletschwald & 16 & $126.9 \pm 91.7$ & $0.48 \pm 0.20$ \\
Larch 05 & Derborence & 19 & $148.3 \pm 70.4$ & $0.74 \pm 0.18$ \\
Maple 07 & Girstel & 11 & $79.0 \pm 20.7$ & $0.98 \pm 0.67$ \\
Maple 21 & Tariche Bois Banal & 16 & $81.7 \pm 11.1$ & $1.06 \pm 0.17$
\end{tabular}




\begin{tabular}{|c|c|c|c|c|}
\hline Maple 39 & Combe Biosse & 11 & $102.3 \pm 19.8$ & $0.67 \pm 0.17$ \\
\hline Scots pine 04 & Pfynwald & 57 & $95.7 \pm 19.7$ & $0.81 \pm 0.25$ \\
\hline Mountain pine 33 & Nationalpark & 160 & $149.0 \pm 53.3$ & $0.57 \pm 0.24$ \\
\hline
\end{tabular}

${ }^{a}$ The names of the sampling groups were derived from the tree species and the forest reserve code (see Table 1),

${ }^{\mathrm{b}} \mathrm{SD}=$ standard deviation

Increment cores were air dried, glued on core mounts and progressively sanded on a belt sander with increasing grit, or cut with a core microtome (Gärtner and Nievergelt, 2010). Prior to measuring, increment cores of maple were stained using Astra blue to facilitate the recognition of the tree rings. Ring widths were measured on a Lintab5 measuring system using the TSAP-Win software (Version 4.69k, both from RINNTECH, Heidelberg, Germany). Crossdating of the dead trees was performed visually and was statistically checked with COFECHA (Holmes, 1983) using corresponding site chronologies from living trees (Bigler and Bugmann, 2003; Rohner, 2008; Rohner et al., 2013; Bigler, 2016; Vanoni et al., 2016). When both cores could be crossdated, only the better preserved core with more tree rings was used for further analysis. Three additional sampling groups of larch and European ash (Fraxinus excelsior) had to be excluded from the analysis (cf. Appendix A.2.).

\subsection{Climate data, drought and frost indices}

We used site-specific climate data from a dataset of daily minimum temperature $\left(T_{\min }\right)$, daily mean temperature $\left(T_{\text {mean }}\right)$ and daily precipitation from 1932 to 2011 that had been interpolated across Switzerland on a grid with 1 ha cell size based on the DAYMET model (Thornton et $a l ., 1997)$ at WSL (Birmensdorf). Interpolation was based on climate station records of MeteoSwiss (Federal Office of Meteorology and Climatology). For the calculation of the drought index (see below), we averaged daily mean temperatures to monthly values and summed up daily precipitation to monthly sums. For the calculation of the frost index (see below), we used daily minimum temperature. 


\subsubsection{Drought index}

We used the Standardized Precipitation Evapotranspiration Index (SPEI) as an indicator for drought (Vicente-Serrano et al., 2010). This multiscalar index incorporates precipitation and potential evapotranspiration, which we estimated based on monthly mean temperatures and latitude using the Thornthwaite method (Thornthwaite, 1948). The calculations of the SPEI were performed using the SPEI package (Beguería et al., 2014) in the statistical software $R$ (R Core Team, 2015).

The most suitable index across all sites and species was found for a six-month time scale, integrating February to July from 1932 to 2011. This included the main growing season for all species, since radial ring growth is basically finished by mid-summer (Ellenberg and Leuschner, 2010). Further information on the SPEI and the correlations between the sites are provided in the Appendix (A.3. and Table A1).

\subsubsection{Frost index}

We tested various simple parameterizations of frost indices, hereafter referred to as FI. In a first step, we averaged daily minimum temperatures $\left(T_{\min }\right)$ and daily mean temperatures $\left(T_{\text {mean }}\right)$ for every day of the year (DOY) to long-term (1932-2011) average daily minimum $\left(\bar{T}_{\text {min }}\right)$ and daily mean temperatures $\left(\bar{T}_{\text {mean }}\right)$ (Appendix Fig. A1). Then, we calculated the daily difference between every negative $T_{\min }$ and $0^{\circ} \mathrm{C}$ (i.e., $\Delta T_{\min }=0^{\circ} \mathrm{C}-T_{\min }$ ). As described above, for most species frost vulnerability is highest in spring, when buds are about to open and leaves or needles are developing. Thus, we only selected those $\Delta T_{\min }$ values after the winter period (which is defined as having $\bar{T}_{\min }<0^{\circ} \mathrm{C}$, hereafter referred to as the frost season). In a last step, the selected $\Delta T_{\min }$ values were added to seasonal sums. To summarize the calculation: The FI consists of "day-degrees" below $0^{\circ} \mathrm{C}\left(\Delta T_{\min }\right)$, added up from the first DOY with $\bar{T}_{\min }>0{ }^{\circ} \mathrm{C}$ (i.e., first day after the frost season, cf. Appendix Table A2) to the end of August for every year from 1932 to 2011 (Appendix Figs. A2, A3). End of August was 
selected to terminate the calculation within a year because $95 \%$ of radial growth of the species is typically finished by then (Ellenberg and Leuschner, 2010), as confirmed by dendrometer measurements even at very high elevations (Carrer et al., 1998). Calculation and analysis of the FI were performed using the statistical software $R$ (R Core Team, 2015).

\subsection{Structural changes in tree growth prior to tree death}

Dying trees often show step-wise growth reductions or continuously decreasing growth rates for several years or decades prior to death (Fig. 2). Hence, we attempted to determine the year in which annual ring growth changed abruptly to higher or lower growth levels. We used the method described by Vanoni et al. (2016) to detect "breakpoints" (i.e., abrupt growth changes). This method does not require any predetermined threshold (e.g., a growth reduction of $25 \%$ ), or a comparison between growth levels of dead and living trees (e.g., Berdanier and Clark, 2016). Multiple horizontal regression lines were fitted to individual tree-ring series to determine the breakpoints (Fig. 2). The only pre-defined model restriction was the minimum length of ten years between breakpoints. The reason was to avoid that an overly high number of consecutive breakpoints was obtained, which would have happened particularly if variability in ring growth was high within a specific period. In the study by Vanoni et al. (2016), all negative breakpoints (i.e., abrupt growth decreases) throughout the life span of each tree were considered. In this study, however, we focused for each tree on the last breakpoint only (i.e., positive or negative breakpoint) before complete growth cessation. The last breakpoints were selected for further analysis only if they were negative (cf. Appendix Table A3). The analysis was performed using the strucchange package (Zeileis et al., 2002) in $R$ (R Core Team, 2015). By applying the function breakpoints (Zeileis et al., 2003), the optimum number of multiple breakpoints in every series was simultaneously estimated using the Bayesian Information Criterion (BIC). A more detailed description of the method can be found in Vanoni et al. (2016). Since this function assigns by default the break dates (i.e., years 
when breakpoints occurred) to the last year of the preceding period, we shifted the break dates by +1 year to the first year of the subsequent period. This shift is required to test the hypothesis that the breakpoints occur in the year or following the year of extreme drought and frost, respectively.
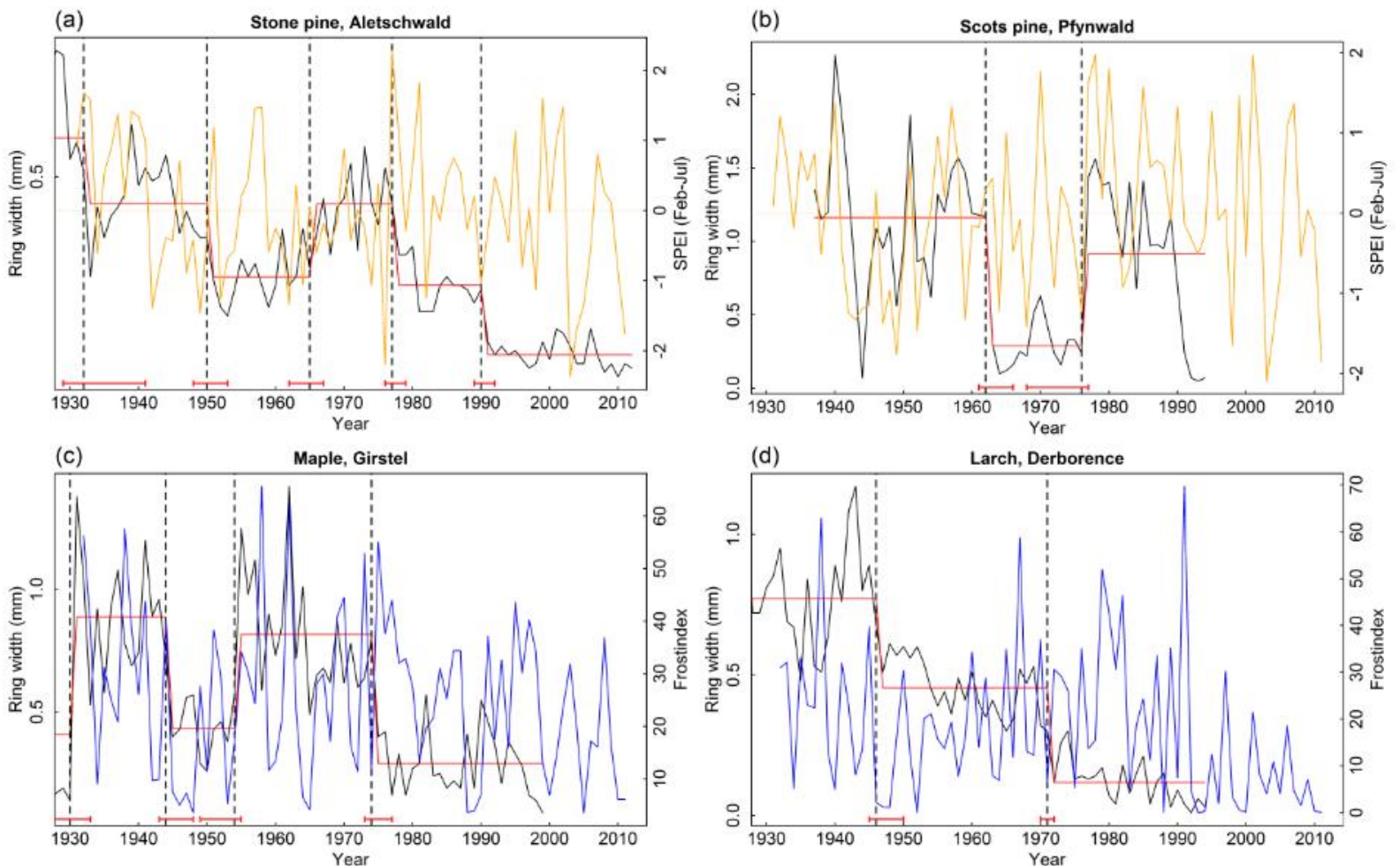

Fig. 2: Illustration of breakpoint detection exemplified with tree-ring series of four species, also showing drought or frost index values: (a) stone pine, site Aletschwald; (b) Scots pine, site Pfynwald; (c) maple, site Girstel; (d) larch, site Derborence. Annual ring widths (black curves), SPEI (orange curves) and FI (blue curves) are shown, as well as fitted regression lines of linear models (red lines), breakpoints (vertical dashed black lines), and confidence intervals of breakpoints (horizontal red lines at the bottom of each panel). The SPEI is standardized, i.e., negative values stand for dry, positive values for moist, and values close to zero for average conditions. The FI is not standardized, i.e., small values indicate warm and large values cold conditions in spring and early summer.

The number of trees considered varied in time among and within sites; hence we calculated the ratio (in percentage) of negative last breakpoints prior to tree death $\left(\mathrm{R}_{\mathrm{bp}}\right)$ for each sampling group in every year (Eqn 1). The total number of trees per site in a given year (t) 
corresponds to $\mathrm{A}_{\mathrm{t}}$, and the number of trees with a negative last breakpoint prior to tree death is denoted as $\mathrm{B}_{\mathrm{t}}$ :

$$
R_{b p, t}=\frac{B_{t}}{A_{t}} \times 100 \%
$$

Eqn 1

\subsection{Distributed lag non-linear models}

We quantified the effects of drought and frost on abrupt growth decreases prior to tree death using the method tested by Vanoni et al. (2016), who related drought and abrupt growth decreases over the complete tree life span. Distributed lag non-linear models (DLNMs) incorporate both the non-linear relationship between the predictors (frost and drought, respectively) and the response (number of negative breakpoints prior to tree death and total number of trees), and a potential lag effect as a result of a delayed growth reaction. To quantify these effects, we considered SPEI and FI values over the last five years. For each sampling group, we fitted a generalized linear model (GLM) with a binomial error distribution as defined by the probability mass function (Eqn 2):

$$
f\left(A_{t} ; B_{t} ; p_{t}\right)=\left(\begin{array}{l}
A_{t} \\
B_{t}
\end{array}\right) \times p_{t}^{B_{t}} \times\left(1-p_{t}\right)^{A_{t}-B_{t}}
$$

The probability $p_{t}$ of a negative breakpoint to occur in year $t$ was modeled with a logit link function (Eqn 3):

$$
\ln \left(\frac{p_{t}}{1-p_{t}}\right)=\alpha+\sum_{l=0}^{5} n s\left(\mathrm{SPEI}_{t-l} ; 2 \mathrm{df}\right)+\sum_{l=0}^{5} n s\left(\mathrm{FI}_{t-l} ; 2 \mathrm{df}\right)+n s(\text { year; } 2 \mathrm{df}), \quad \text { Eqn } 3
$$

where $\alpha$ is the intercept. A natural cubic spline function $(n s)$ with 2 degrees of freedom (df) allowed for non-linear relationships and was applied to the drought index $\left(\mathrm{SPEI}_{\mathrm{t}-1}\right)$ and the frost index $\left(\mathrm{FI}_{\mathrm{t}-\mathrm{l}}\right)$ lagged from 0 to 5 years $(l)$. To consider long-term trends in the number of observations (e.g., fewer observations in more recent times due to the dropping out of dead 
trees), we also included the variable "year" with a natural cubic spline function and $2 \mathrm{df}$. In the model, eleven coefficients were estimated, i.e. one coefficient for the intercept, four each for drought and frost, respectively, and two for the variable year. In a further step, odds ratios of observing a negative breakpoint were calculated for all sampling groups separately for the complete ranges of SPEI and FI values for each site and lags from zero to five years. Odds ratios are the ratio of the odds $\left(p_{t} /\left(1-p_{t}\right)\right)$ of a negative breakpoint to occur at a specific SPEI or FI value to the odds of a negative breakpoint to occur at a reference SPEI or FI. In our analysis, the site-specific maximum SPEI and the lowest FI, respectively, of the time series were used as reference values. The model design for predictions of the odds ratios was thus based on the assumption that no negative breakpoints are expected under the moistest and warmest conditions, respectively. The odds ratio is a relative measure of the effect that drought and frost, respectively, have on the occurrence of negative breakpoints, i.e. odds ratios $>1$ show an increased "risk" of negative breakpoints compared to the reference value, whereas odds ratios <1 suggest a reduced "risk" of observing negative breakpoints. Calculations were performed using the packages $d \operatorname{lnm}$ (Gasparrini, 2011) and splines in $R(\mathrm{R}$ Core Team, 2015).

We fitted and compared models with different parameterizations of the drought and frost index and finally decided for the lengths and periods of the SPEI and FI as described above. Additional models including either frost or drought as a single predictor resulted in similar results of the predictions compared to the model that included both drought and frost in a linear combination. Interactions between frost and drought were not considered in the model. 


\section{Results}

The occurrence of abrupt growth decreases prior to tree death varied across the 22 sampling groups over time (Fig. 3). Due to the investigated lag effect of drought and frost from zero to five years, only breakpoints from 1937 to 2011 could be considered for the analysis. The maximum ratio of negative breakpoints across all sampling groups was found for spruce in Leihubel, where 3 of 7 living trees (43\%) showed an abrupt growth decrease in the year 2000. Further high breakpoint ratios were found - in descending order - for maple in Combe Biosse (33\% in 1978), oak in Bois de Chênes (22\% in 1965), beech in Weidwald (18\% in 1976), spruce in Leihubel (18\% in 1991), and maple in Combe Biosse (1945, 18\%). Ratios of 17\% were found for spruce in Scatlè (1986), larch in Aletschwald (1975), larch in Derborence (1972, 1993), and maple in Girstel (1983, 1985, 1987). High breakpoint ratios in the 22 sampling groups coincided in some years with increased frost and drought values, respectively. This was the case, for example, for oak in Bois de Chênes in 1965, when in 22\% of the trees a negative last breakpoint prior to tree death occurred, while the frost index (FI) was 32.4 (average FI = 16.2 in Bois de Chênes from 1932 to 2011). The ratio of $18 \%$ for spruce in Leihubel in 1991 coincided with a comparably cold late spring/early summer (FI = 52.7 compared to an average FI of 25.6 in Leihubel, cf. Appendix Fig. A2), and the breakpoint ratio of $18 \%$ in maple in Combe Biosse coincided with a dry spring season in 1945 $(\mathrm{SPEI}=-1.2)$ 


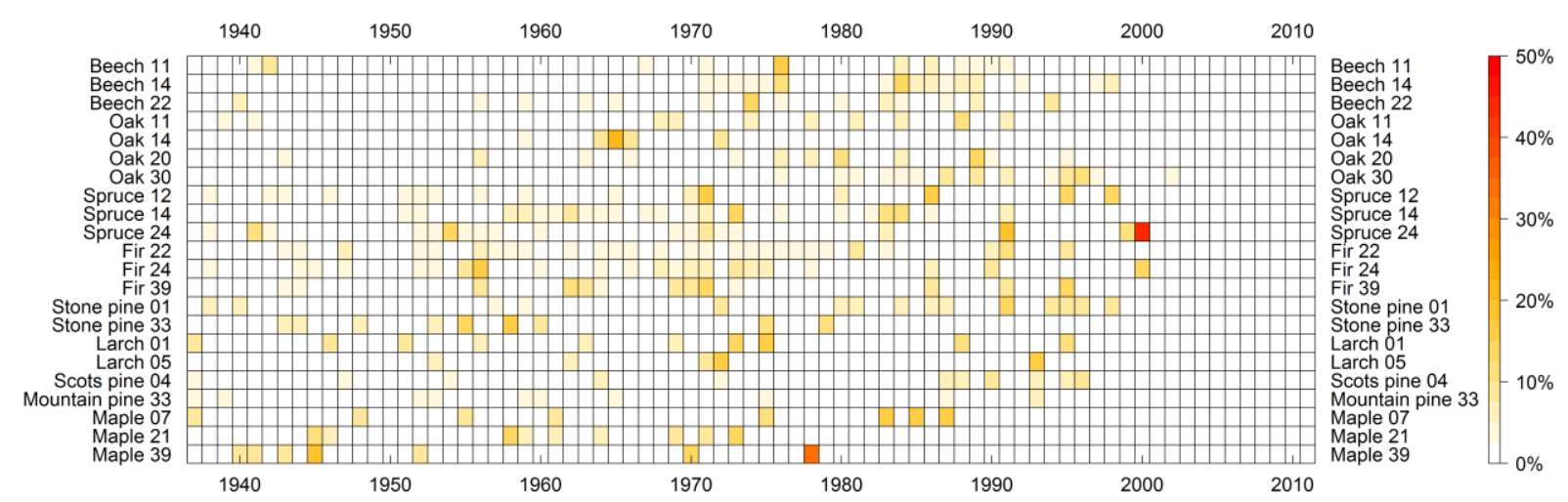

Fig. 3: Breakpoint ratios (Eqn 1) of all sites. For explanations of sampling groups (labels on the y-axis), cf. Table 2.

In nine of the 22 sampling groups, negative last breakpoints prior to tree death were detected in all of the trees (cf. Appendix, Table A3). In the other sampling groups, between $63 \%$ and $98 \%$ of all trees showed a negative last breakpoint prior to tree death (e.g., negative last breakpoints in Figs. 2a, c, d; positive last breakpoint in Fig. 2b). The lowest ratio of $63 \%$ was found for larch in Derborence, where only 12 out of 19 trees showed a negative last breakpoint prior to death. In most cases, breakpoints occurred several decades before tree death, with a mean value of 31.7 years (standard error: \pm 4.01 ) across all sampling groups (cf. Appendix, Table A3).

Severe drought (i.e., lowest site-specific SPEI value) resulted in increased odds ratios of abrupt growth decreases for several species (Fig. 4), albeit they did not significantly differ from 1 in most sampling groups. For beech in Weidwald and Bois de Chênes the odds ratios were significantly increased at lags 0 and 0-2, respectively (Fig. 5). A lagged effect of significantly increased odds ratios after 4-5 years was found for Scots pine in Pfynwald. In contrast, significantly decreased odds ratios implying a lower risk of abrupt growth decreases to occur were predicted for stone pine in Aletschwald (years 0-2), for fir in Combe Biosse (years 3-5), for oak in Bois de Chênes (years 0-2) and Strassberg (years 0-2), and for beech in Weidwald (years 4-5). 

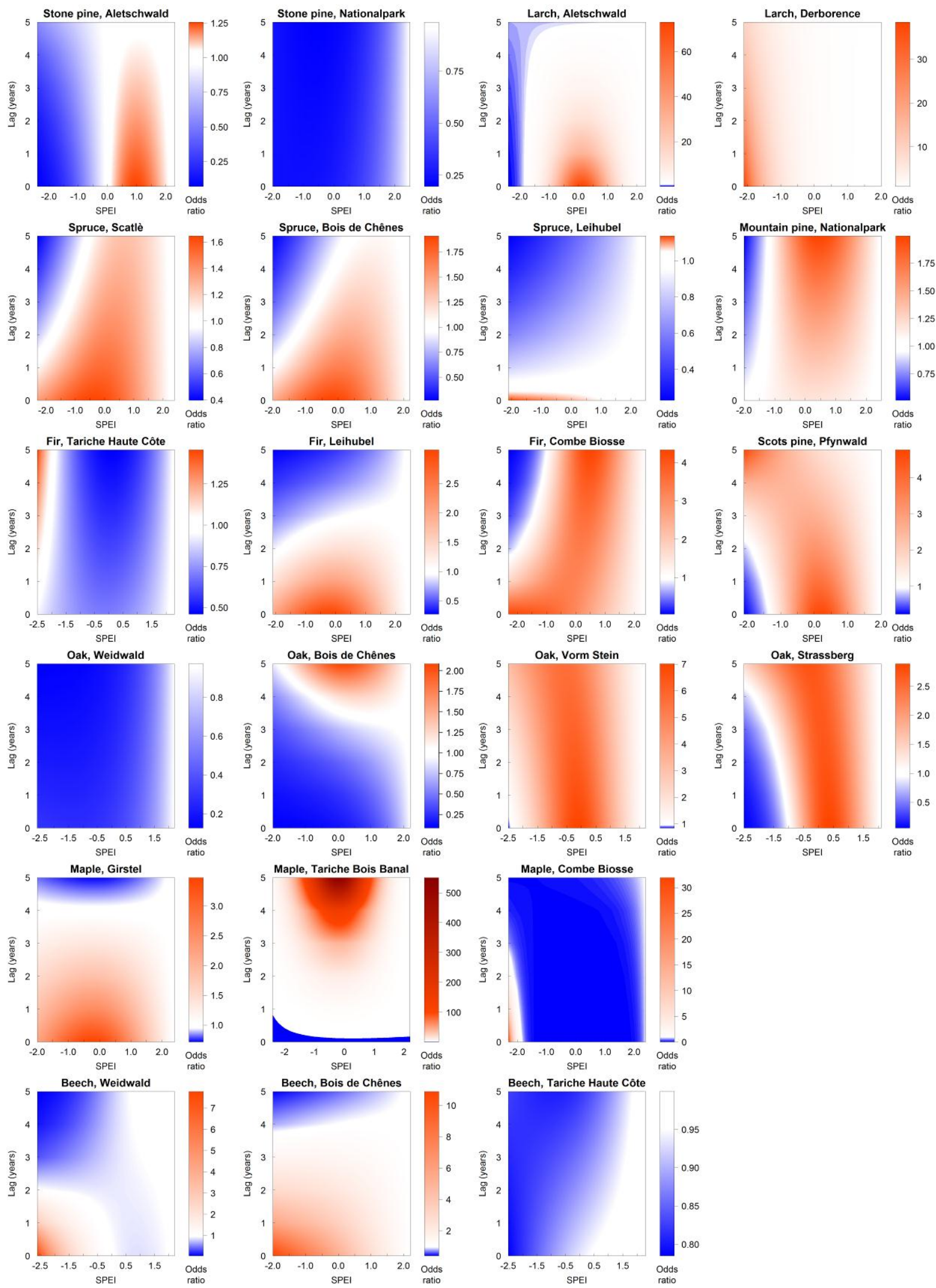

Fig. 4: Odds ratios of a negative breakpoint to occur at different SPEI values (range of X-axis based on sitespecific SPEI values) with lags from 0 to 5 years (y-axis). Odds ratios equal 1 at maximum SPEI on each site (reference value). The color gradient ranges from blue to white (representing lowest odds ratios to odds ratios of 
1), from white to orange (odds ratios between 1 and 100), and - if values are present - from orange to red (odds ratios $>100$ ). For significance levels of the odds ratios at lowest SPEI values per sampling group cf. Fig. 5.

Panels within species are listed in ascending order of forest reserve codes (cf. Table 1). 

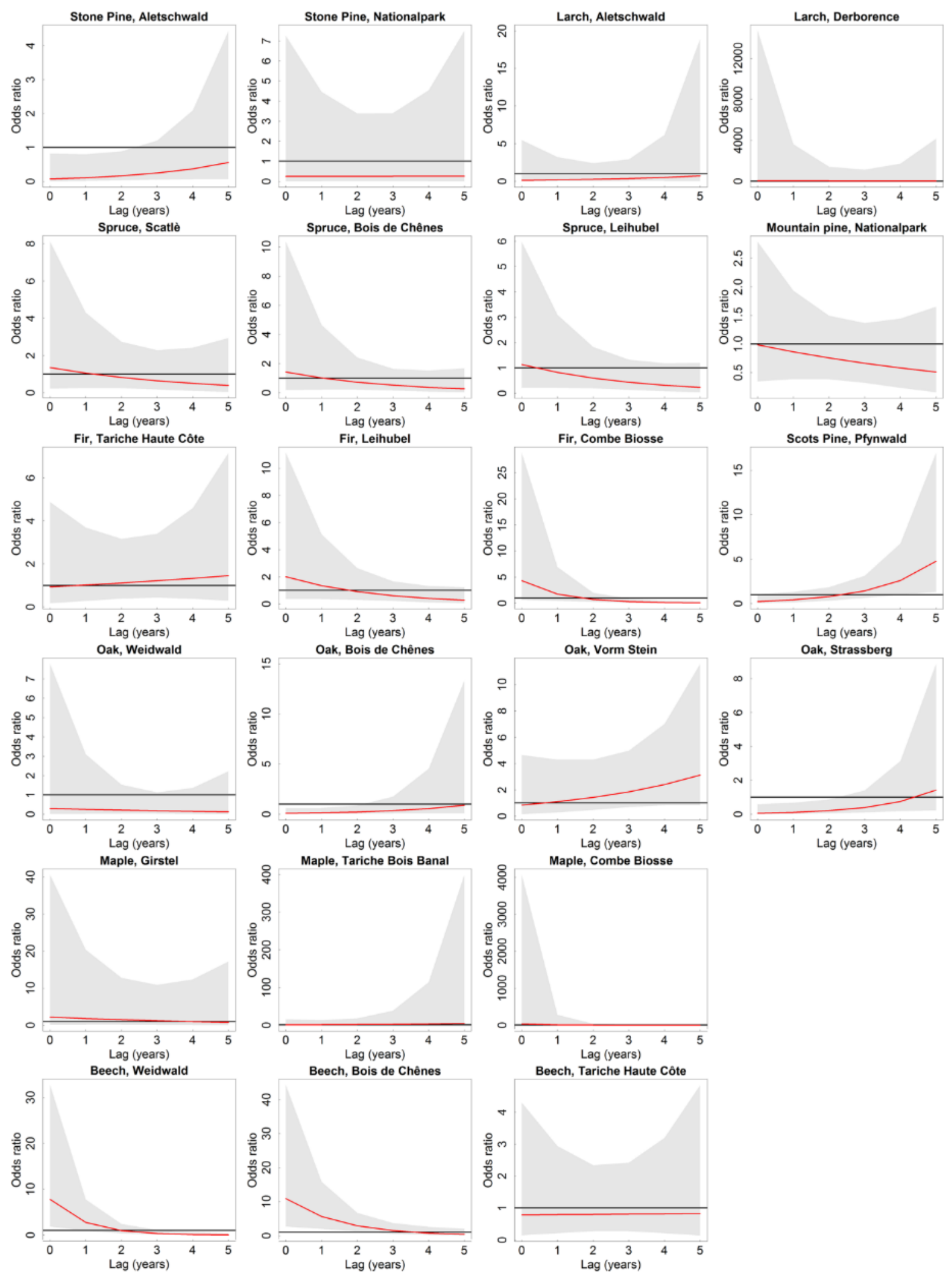

Fig. 5: Estimated odds ratios (red curves) including 95\% confidence intervals (gray) for site-specific minimum SPEI values (i.e., most severe droughts) from lag 0 (year of drought event) to lag 5 (five years after drought event). Black lines denote an odds ratio of 1 . Scales of the y-axis differ to facilitate the identification of significant values. Panels within species are listed in ascending order of forest reserve codes (cf. Table 1). 
Regarding the odds ratios after frost, the predictions of negative breakpoints showed increased odds ratios for some species under highest frost index values (per site), i.e., in the current growing season starting immediately in the year of the frost or lagged for the subsequent years (Fig. 6). However, only for beech in Weidwald (years 2-4) and Bois de Chênes (years 0-4), the odds ratios were significantly increased (at 5\% significance level) during or shortly after the most severe frost event (Fig. 7). In contrast, odds ratios were significantly decreased after some years for spruce in Bois de Chênes (years 4-5) and fir in Leihubel (years 4-5). For all the other sites and species, neither significantly increased nor decreased odds ratios were found at any lag from zero to five years after frost. 

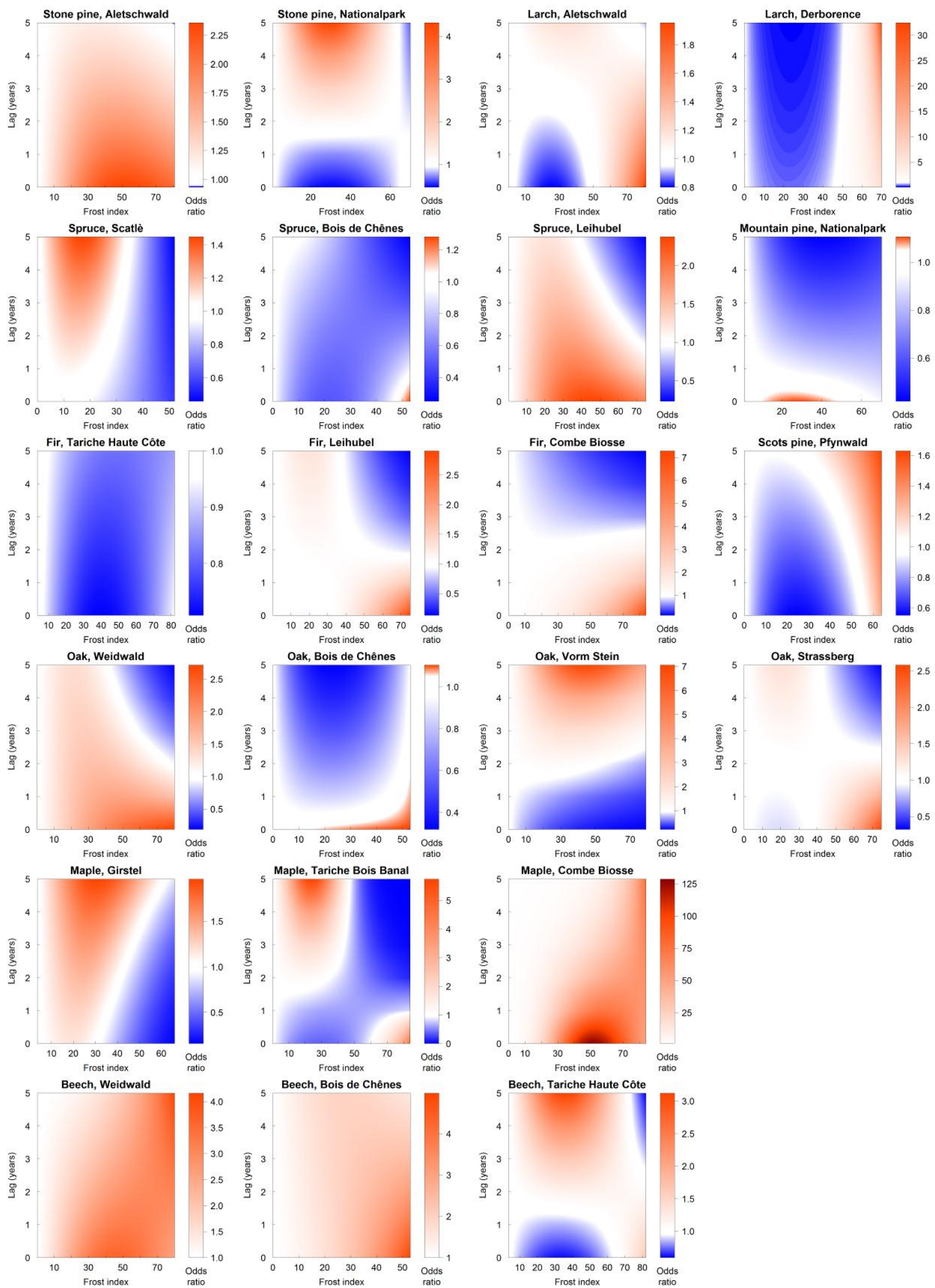

Fig. 6: Odds ratios of a negative breakpoint to occur at different frost index $\left(T_{m i n}\right)$ values (range of $\mathrm{x}$-axis based on site-specific frost index values) with lags from 0 to 5 years (y-axis). Odds ratios equal 1 at minimum frost index on each site (reference value). The color gradient ranges from blue to white (representing lowest odds 
ratios to odds ratios of 1), from white to orange (odds ratios between 1 and 100), and - if values are present from orange to red (odds ratios $>100$ ). For significance levels of the odds ratios at lowest SPEI values per sampling group cf. Fig. 7. Panels within species are listed in ascending order of forest reserve codes (cf. Table 1). 

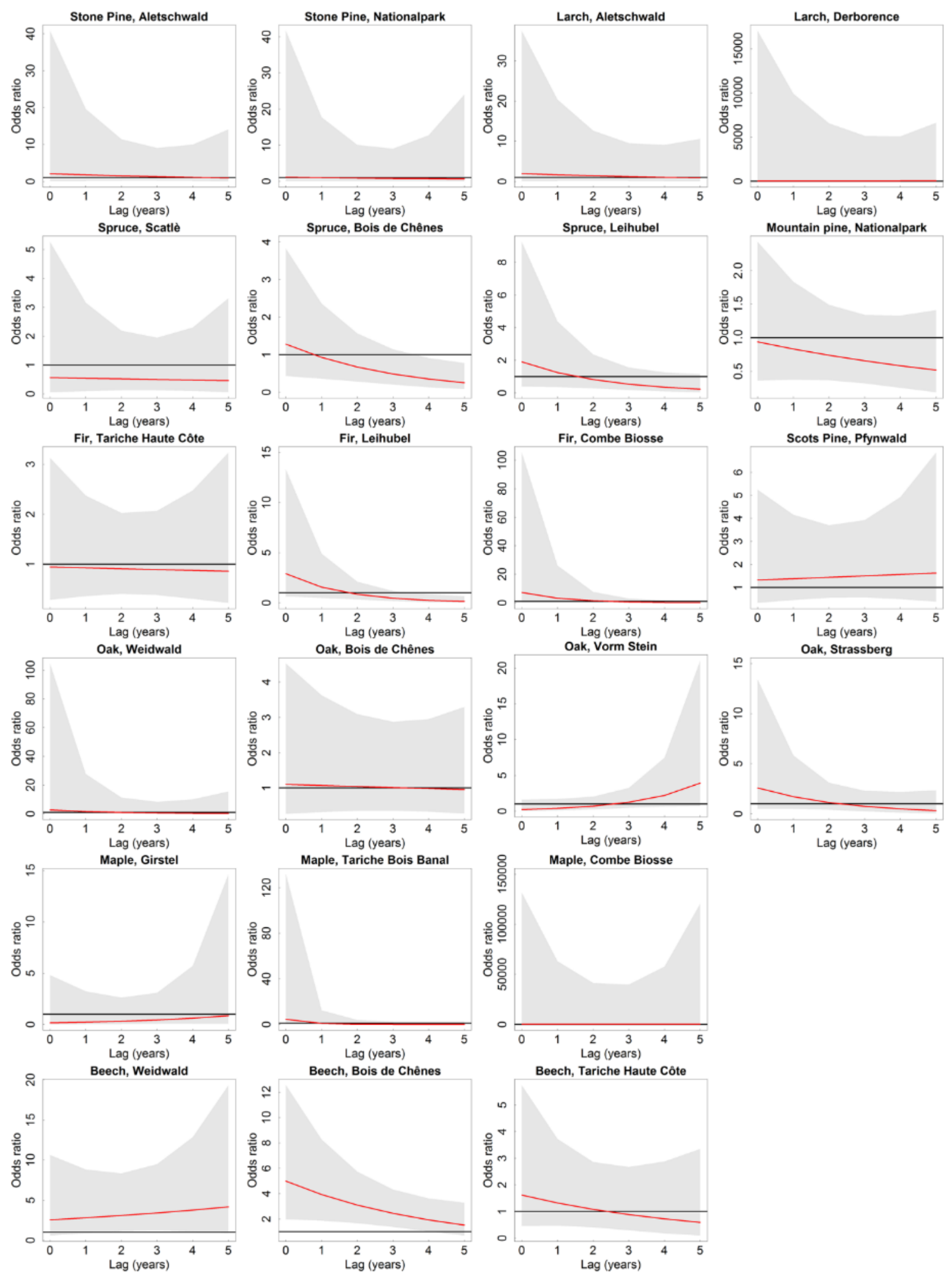

Fig. 7: Estimated odds ratios (red curves) including 95\% confidence intervals (gray) for site-specific maximum frost index values (i.e., most severe frost) from lag 0 (year of frost event) to lag 5 (five years after frost event). Black lines denote an odds ratio of 1 . Scales of the y-axis differ to facilitate the identification of significant values. Panels within species are listed in ascending order of forest reserve codes (cf. Table 1). 


\section{Discussion}

In the vast majority of the dead trees, abrupt negative growth changes were identified prior to tree death. Distributed lag non-linear models allowed for linking climate variability with abrupt growth responses: the drought- and frost-sensitivity of the nine species (as described by Ellenberg and Leuschner (2010)) were typically well reflected in increased odds ratios of abrupt growth decreases. Thus, extreme drought (Allen et al., 2010) and frost (Frank et al., 2015) are two prominent inciting factors of tree mortality for many temperate tree species. While frost tends to act immediately and may force abrupt growth decreases that are starting in the year of the climate extreme, drought impacts are often lagged by some years.

However, for many sampling groups only marginally significant or insignificant effects were found that in some cases resulted in large confidence intervals for the predicted odds ratios (Figs. 5, 7). This was most likely caused by the comparably low sample size for some species, particularly for maple, stone pine and larch (cf. Appendix Table A3). Thus, our results confirm that within-species as well as among-species variability of the response to drought and frost are high (Malyshev et al., 2016), since the odds ratios that should reflect tolerance of drought and late frosts varied considerably among sampling groups within the same species along the environmental gradient. Marginally significant effects were likely caused by (i) the method of breakpoint detection that includes some uncertainty; (ii) the model assumptions for the predictions (i.e., no breakpoints under moistest and warmest conditions are expected); and (iii) the large number of coefficients that had to be estimated in the fitting of the GLMs.

On average, in $92 \%$ of all cases a negative last breakpoint some years to decades prior to tree death was detected (Appendix Table A3). In the other 8\%, (i) growth decrease prior to tree death must either have arisen in such a short period that our detection method did not characterize this as a change to a lower growth level, (ii) gradually declining growth preceded 
tree death, or (iii) tree death occurred instantly (e.g., by wind breakage) even though we tried to avoid disturbances as a mortality cause in the field sampling.

\subsection{Drought impact}

A clear relationship between drought and abrupt negative growth changes prior to tree death was identified in several species. For Scots pine, which is thought to feature very low sensitivity to drought, we found drought impacts, i.e. a significantly increased risk of breakpoints to occur after a lag of several years. However, high odds ratios at mean SPEI values (Fig. 4) suggest that for this species other factors in years with average drought conditions contributed strongly to the negative last breakpoints. Stone pine, which has very low sensitivity to drought (Anfodillo et al., 1998), did not experience a higher risk of negative last breakpoints under extreme drought conditions at both sites Aletschwald and Nationalpark. In contrast, predicted odds ratios were even significantly decreased during and shortly after drought in Aletschwald (Fig. 5). This implies that breakpoints were most likely not induced by drought at these two sites, contradicting the assumptions of Boden et al. (2010) for this species. For oak, another species considered to have low drought sensitivity (Ellenberg and Leuschner, 2010), strong relations between abrupt growth decreases that occurred several years following drought during all life stages were recently reported (Vanoni et al., 2016). Correspondingly, the lagged impact of drought on negative growth changes before tree death was notable in Vorm Stein and Strassberg (Fig. 5).

On the lowest-elevation fir site, Tariche Haute Côte, slightly increased, but non-significant odds ratios were found some years after drought. In Leihubel and Combe Biosse, odds ratios were increased during and shortly after drought, but switched to significantly decreased values after three to five years in Combe Biosse (Fig. 5). This outcome reflects the medium sensitivity of fir to drought (Ellenberg and Leuschner, 2010), but also underpins the variable reaction to drought of fir at different elevations (van der Maaten-Theunissen et al., 2013; 
Cailleret et al., 2014). For maple, another species considered to have medium drought sensitivity (Ellenberg and Leuschner, 2010), there was a slightly increased risk in Girstel and Combe Biosse, but an exceptional pattern in Tariche Bois Banal that indicated no reaction to drought whatsoever.

The impact of drought on larch, which is described being sensitive to drought (Charra-Vaskou et al., 2011; Lévesque et al., 2013), was more apparent at medium (Derborence) than at high elevations (Aletschwald; Fig. 4). Beech is considered highly vulnerable to drought (Ellenberg and Leuschner, 2010), which often implies poor perspectives compared to oak or spruce under projected climate change (Zang et al., 2014). However, local adaptation can result in very diverse reactions of beech to drought (Thiel et al., 2014), confirmed by two of our sampling groups: beech showed significantly increased odds ratios in Weidwald in the current year, and in the current and subsequent years in Bois de Chênes, respectively (Fig. 5).

Besides beech, spruce is often characterized as the most vulnerable Central European species under projected climate change (Zang et al., 2014). In fact, drought was important at all spruce sites, leading to an increased odds ratio of negative last breakpoints during the most severe drought, albeit they were non-significant. Nevertheless, this tendency underlines the high risk of spruce under drought at all elevations (van der Maaten-Theunissen et al., 2013).

\subsection{Frost impact}

Overall, the impact of frost was found to be less prominent than the impact of drought, but in the more sensitive species there was evidence of frost-incited growth decreases. The high frost tolerance of Scots pine (Leinonen et al., 1997) does not imply a complete lack of sensitivity to frost, but rather a delayed reaction, since slightly increased, but non-significant odds ratios were identified at all lags (Fig. 7). The non-significant outcome of the odds ratios after frost at both stone pine sites was expected, as its sensitivity to frost is very low 
(Oberhuber et al., 2008). However, the main drivers of mortality in stone pine remain unclear, as drought did not show any effects on growth decreases either. Likewise, frost-tolerant mountain pine in Nationalpark did not exhibit any reaction, concurring with previous findings in the same region (Dobbertin et al., 2001).

Maple is characterized as being relatively tolerant of late spring frosts (Hein et al., 2009) owing to a longer thermal time required for budburst than beech, Scots pine, or oak (Charrier et al., 2013). However, there was evidence of immediate frost impacts on abrupt growth reductions for maple in Tariche Bois Banal and Combe Biosse (Fig. 6). In contrast, at the lower site Girstel frost did not incite abrupt decreases prior to tree death. Frost impacts on larch were found at both sites to some extent, although larch is described to be only medium sensitive to frost (Charra-Vaskou et al., 2011). The medium sensitivity of spruce to frost (Charra-Vaskou et al., 2011) was reflected at the two low-elevation sites Bois de Chênes and Leihubel, with slightly increased odds ratios during frost that switched to significantly decreased values in Bois de Chênes after four to five years. In oak, the non-significant odds ratios emphasize its medium sensitivity to frost. Although the risk of late frosts may have increased in the last decades due to an earlier onset of growth (Scharnweber et al., 2011), oaks are well-adapted to late frost by delaying the time of flushing (Dantec et al., 2015).

Fir is not only highly sensitive to deep frost in winter (Lebourgeois, 2007), but also to late frost events, which became evident at two of our sites: in Leihubel, where the odds ratios switched from increased values during the first few years to significantly decreased values after four to five years - similar to the pattern for drought - and in Combe Biosse (Fig. 7). This is in good agreement with drought and frost being identified as important limiting factors for fir (Desplanque et al., 1999). In beech, the variability of frost hardiness is very diverse between provenances (Hofmann et al., 2015), but the generally high frost vulnerability of this 
species was reflected in an increased risk at all three sites, albeit the odds ratios differed significantly from 1 in Weidwald (years 2-4) and Bois de Chênes (years 0-4) only.

\subsection{Additional factors}

Besides the influence of drought and frost on the occurrence of abrupt growth decreases that we were able to detect in many tree species, several other abiotic or biotic processes may act as triggers for tree death, either as predisposing, inciting or contributing factors (Manion, 1991), or as a combination thereof. Complex interactions of several factors in addition to drought and frost, such as fungi or insects were identified e.g. for Scots pine (Wermelinger et al., 2008; Rigling et al., 2010; Eilmann et al., 2013), although stand-related effects may play a crucial role in some growth responses (Sánchez-Salguero et al., 2015). In Nationalpark, the contribution of fungal root pathogens is partly accountable for tree death in mountain pine (Cherubini et al., 2002). In general, trees at higher elevations in the European Alps are not water-limited (van der Maaten-Theunissen et al., 2013), which became apparent for larch, stone pine and mountain pine in Aletschwald and Nationalpark (Fig. 4). Particularly in those high-elevation areas but also in other areas, additional factors may need to be considered, such as a prolonged snow cover, which may play a more important role than drought or frost (Boden et al., 2010).

The statistical framework that we applied did not allow us to distinguish between the factors triggering tree decline, but we nevertheless were able to demonstrate in many cases that this framework can serve to elucidate relationships between climatic factors and growth responses of tree species that are known to be sensitive to drought and frost, respectively. However, many factors such as bark beetle outbreaks, pathogens, wind- and snow-breakage and other biotic and abiotic factors may further contribute to tree death. 


\section{Conclusions}

A majority of the trees in our large sample featured abrupt growth decreases several years up to several decades prior to tree death. Drought and frost were identified to act as inciting factors of these abrupt growth decreases, which depended on the species-specific drought and late frost tolerances as well as site effects.

Although the uniformly applied parameterization of frost and drought (i.e. the same period of the year across all elevations was used) may not account for exceptional events such as extreme deep frost during winter or droughts of longer and shorter periods, it allowed us to compare the species' reaction under diverse site conditions as well as in different size and age classes, and leads to reasonable results. Abrupt growth reductions after drought were commonly more prominent but less instantaneous than after frost.

Assessing the current risk of frost and drought as the two major climatic factors that induce abrupt growth changes and thus impact long-term growth patterns is crucial to improve our understanding of future forest dynamics. An increasing risk of drought is consistently reported for the $21^{\text {st }}$ century, whereas the projection of frost risk is less consistent (Rixen et al., 2012; Morin and Chuine, 2014). Numerous reports on recent drought-induced tree mortality events underpin the importance of drought impacts on long-term forest dynamics. With shorter expected frost periods under future climate (Scheifinger et al., 2003), trees could either profit and increase their growth, or frost periods after earlier growing season onsets could cause damage to opening buds and unfolding leaves. 


\section{Acknowledgements}

We thank Lisa Hülsmann and Brigitte Rohner from WSL (Birmensdorf) for providing inventory and tree-ring data of the forest reserves, and the colleagues from the Forest Ecology group at ETH who were involved in the field campaign or sample processing in the tree-ring laboratory. We acknowledge the support and the permissions from the forest service authorities, the Swiss National Park administration, Pro Natura Valais and the Swiss network of strict forest reserves from ETH, WSL and the Swiss Federal Office for the Environment (FOEN).

Funding: This study was supported by the Swiss National Science Foundation within the project "Predicting growth-dependent tree mortality: a key challenge for population ecology" (project number 140968). The financial support by the FOEN (Federal Office for the Environment) for the Swiss network of strict forest reserves and by the Swiss National Park is gratefully acknowledged. 


\section{References}

Adame, P., del Rio, M., Canellas, I., 2010. Modeling individual-tree mortality in Pyrenean oak (Quercus pyrenaica Willd.) stands. Ann Forest Sci 67.

Alenius, V., Hokka, H., Salminen, H., Jutras, S., 2003. Evaluating estimation methods for logistic regression in modelling individual-tree mortality. In, Modelling Forest Systems, pp. 225-236.

Allen, C.D., Macalady, A.K., Chenchouni, H., Bachelet, D., McDowell, N., Vennetier, M., Kitzberger, T., Rigling, A., Breshears, D.D., Hogg, E.H., Gonzalez, P., Fensham, R., Zhang, Z., Castro, J., Demidova, N., Lim, J.H., Allard, G., Running, S.W., Semerci, A., Cobb, N., 2010. A global overview of drought and heat-induced tree mortality reveals emerging climate change risks for forests. Forest Ecol Manag 259, 660-684.

Anderegg, L.D.L., HilleRisLambers, J., 2016. Drought stress limits the geographic ranges of two tree species via different physiological mechanisms. Global Change Biol 22, 1029-1045.

Anderegg, W.R.L., Berry, J.A., Smith, D.D., Sperry, J.S., Anderegg, L.D.L., Field, C.B., 2012. The roles of hydraulic and carbon stress in a widespread climate-induced forest die-off. P Natl Acad Sci USA 109, 233-237.

Anderegg, W.R.L., Hicke, J.A., Fisher, R.A., Allen, C.D., Aukema, J., Bentz, B., Hood, S., Lichstein, J.W., Macalady, A.K., McDowell, N., Pan, Y., Raffa, K., Sala, A., Shaw, J.D., Stephenson, N.L., Tague, C., Zeppel, M., 2015a. Tree mortality from drought, insects, and their interactions in a changing climate. New Phytol 208, 674-683.

Anderegg, W.R.L., Schwalm, C., Biondi, F., Camarero, J.J., Koch, G., Litvak, M., Ogle, K., Shaw, J.D., Shevliakova, E., Williams, A.P., Wolf, A., Ziaco, E., Pacala, S., 2015b. Pervasive 
drought legacies in forest ecosystems and their implications for carbon cycle models. Science $349,528-532$.

Anfodillo, T., Rento, S., Carraro, V., Furlanetto, L., Urbinati, C., Carrer, M., 1998. Tree water relations and climatic variations at the alpine timberline: seasonal changes of sap flux and xylem water potential in Larix decidua Miller, Picea abies (L.) Karst, and Pinus cembra L. Ann Sci Forest 55, 159-172.

Beguería, S., Vicente-Serrano, S.M., Reig, F., Latorre, B., 2014. Standardized precipitation evapotranspiration index (SPEI) revisited: parameter fitting, evapotranspiration models, tools, datasets and drought monitoring. International Journal of Climatology 34, 3001-3023.

Berdanier, A.B., Clark, J.S., 2016. Multiyear drought-induced morbidity preceding tree death in southeastern U.S. forests. Ecol Appl 26, 17-23.

Bigler, C., 2016. Trade-Offs between Growth Rate, Tree Size and Lifespan of Mountain Pine (Pinus montana) in the Swiss National Park. PLoS ONE 11, e0150402.

Bigler, C., Bugmann, H., 2003. Growth-dependent tree mortality models based on tree rings. Canadian Journal of Forest Research 33, 210-221.

Boden, S., Pyttel, P., Eastaugh, C., 2010. Impacts of climate change on the establishment, distribution, growth and mortality of Swiss stone pine (Pinus cembra L.). iForest Biogeosciences and Forestry 3, 82-85.

Bond-Lamberty, B., Rocha, A.V., Calvin, K., Holmes, B., Wang, C., Goulden, M.L., 2014. Disturbance legacies and climate jointly drive tree growth and mortality in an intensively studied boreal forest. Global Change Biol 20, 216-227. 
Brang, P., Heiri, C., Bugmann, H., 2011. Waldreservate: 50 Jahre natürliche

Waldentwicklung in der Schweiz. Haupt, Bern, Switzerland.

Cailleret, M., Nourtier, M., Amm, A., Durand-Gillmann, M., Davi, H., 2014. Droughtinduced decline and mortality of silver fir differ among three sites in Southern France. Ann Forest Sci 71, 643-657.

Cannell, M.G.R., Smith, R.I., 1986. Climatic Warming, Spring Budburst and Frost Damage on Trees. J Appl Ecol 23, 177-191.

Carrer, M., Anfodillo, T., Urbinati, C., Carraro, V., 1998. High-altitude forest sensitivity to global warming: results from long-term and short-term analyses in the eastern italian alps. In: Beniston, M., Innes, J.L. (Eds.), The Impacts of Climate Variability on Forests. Springer Berlin Heidelberg, Berlin, Heidelberg, pp. 171-189.

Charra-Vaskou, K., Charrier, G., Wortemann, R., Beikircher, B., Cochard, H., Ameglio, T., Mayr, S., 2011. Drought and frost resistance of trees: a comparison of four species at different sites and altitudes. Ann Forest Sci 69, 325-333.

Charrier, G., Cochard, H., Ameglio, T., 2013. Evaluation of the impact of frost resistances on potential altitudinal limit of trees. Tree Physiol. 33, 891-902.

Charrier, G., Ngao, J., Saudreau, M., Améglio, T., 2015. Effects of environmental factors and management practices on microclimate, winter physiology, and frost resistance in trees. Frontiers in Plant Science 6, 259.

Cherubini, P., Fontana, G., Rigling, D., Dobbertin, M., Brang, P., Innes, J.L., 2002. Tree-life history prior to death: two fungal root pathogens affect tree-ring growth differently. Journal of Ecology 90, 839-850. 
Clark, J.S., Iverson, L., Woodall, C.W., Allen, C.D., Bell, D.M., Bragg, D.C., D'Amato, A.W., Davis, F.W., Hersh, M.H., Ibanez, I., Jackson, S.T., Matthews, S., Pederson, N., Peters, M., Schwartz, M.W., Waring, K.M., Zimmermann, N.E., 2016. The impacts of increasing drought on forest dynamics, structure, and biodiversity in the United States. Global Change Biol 22, 2329-2352.

Dantec, C.F., Ducasse, H., Capdevielle, X., Fabreguettes, O., Delzon, S., Desprez-Loustau, M.-L., 2015. Escape of spring frost and disease through phenological variations in oak populations along elevation gradients. Journal of Ecology 103, 1044-1056.

Desplanque, C., Rolland, C., Schweingruber, F.H., 1999. Influence of species and abiotic factors on extreme tree ring modulation. Trees 13, 218-227.

Dittmar, C., Fricke, W., Elling, W., 2006. Impact of late frost events on radial growth of common beech (Fagus sylvatica L.) in Southern Germany. Eur J Forest Res 125, 249-259.

Dobbertin, M., Baltensweiler, A., Rigling, D., 2001. Tree mortality in an unmanaged mountain pine (Pinus mugo var. uncinata) stand in the Swiss National Park impacted by root rot fungi. Forest Ecol Manag 145, 79-89.

Eilmann, B., Dobbertin, M., Rigling, A., 2013. Growth response of Scots pine with different crown transparency status to drought release. Ann Forest Sci 70, 685-693.

Ellenberg, H., Leuschner, C., 2010. Vegetation Mitteleuropas mit den Alpen in ökologischer, dynamischer und historischer Sicht. Ulmer, Stuttgart, Germany.

Frank, D., Reichstein, M., Bahn, M., Thonicke, K., Frank, D., Mahecha, M.D., Smith, P., van der Velde, M., Vicca, S., Babst, F., Beer, C., Buchmann, N., Canadell, J.G., Ciais, P., Cramer, W., Ibrom, A., Miglietta, F., Poulter, B., Rammig, A., Seneviratne, S.I., Walz, A., Wattenbach, M., Zavala, M.A., Zscheischler, J., 2015. Effects of climate extremes on the 
terrestrial carbon cycle: concepts, processes and potential future impacts. Global Change Biol 21, 2861-2880.

Franklin, J.F., Shugart, H.H., Harmon, M.E., 1987. Tree death as an ecological process. Bioscience 37, 550-556.

Gärtner, H., Nievergelt, D., 2010. The core-microtome: A new tool for surface preparation on cores and time series analysis of varying cell parameters. Dendrochronologia 28, 85-92.

Gasparrini, A., 2011. Distributed lag linear and non-linear models in R: The package dlnm. J Stat Softw 43, 1-20.

Haavik, L.J., Billings, S.A., Guldin, J.M., Stephen, F.M., 2015. Emergent insects, pathogens and drought shape changing patterns in oak decline in North America and Europe. Forest Ecol Manag 354, 190-205.

Hartmann, H., 2011. Will a 385 million year-struggle for light become a struggle for water and for carbon? - How trees may cope with more frequent climate change-type drought events. Global Change Biol 17, 642-655.

Hawkes, C., 2000. Woody plant mortality algorithms: description, problems and progress. Ecol Model 126, 225-248.

Hein, S., Collet, C., Ammer, C., Goff, N.L., Skovsgaard, J.P., Savill, P., 2009. A review of growth and stand dynamics of Acer pseudoplatanus L. in Europe: implications for silviculture. Forestry 82, 361-385.

Herbst, M., Mund, M., Tamrakar, R., Knohl, A., 2015. Differences in carbon uptake and water use between a managed and an unmanaged beech forest in central Germany. Forest Ecol Manag 355, 101-108. 
Hofmann, M., Durka, W., Liesebach, M., Bruelheide, H., 2015. Intraspecific variability in frost hardiness of Fagus sylvatica L. Eur J Forest Res 134, 433-441.

Holmes, R.L., 1983. Computer-assisted quality control in tree ring dating and measurement. Tree-Ring Bulletin 43, 69-78.

Holzwarth, F., Kahl, A., Bauhus, J., Wirth, C., 2013. Many ways to die - partitioning tree mortality dynamics in a near-natural mixed deciduous forest. Journal of Ecology 101, 220230.

Kozlowski, T.T., Pallardy, S.G., Kramer, P.J., 1991. The physiological ecology of woody plants. Academic Press, San Diego.

Lebourgeois, F., 2007. Climatic signal in annual growth variation of silver fir (Abies alba Mill.) and spruce (Picea abies Karst.) from the French Permanent Plot Network (RENECOFOR). Ann Forest Sci 64, 333-343.

Lebourgeois, F., Rathgeber, C.B.K., Ulrich, E., 2010. Sensitivity of French temperate coniferous forests to climate variability and extreme events (Abies alba, Picea abies and Pinus sylvestris). J Veg Sci 21, 364-376.

Leinonen, I., Repo, T., Hänninen, H., 1997. Changing environmental effects on frost hardiness of Scots pine during dehardening. Ann Bot-London 79, 133-138.

Lévesque, M., Saurer, M., Siegwolf, R., Eilmann, B., Brang, P., Bugmann, H., Rigling, A., 2013. Drought response of five conifer species under contrasting water availability suggests high vulnerability of Norway spruce and European larch. Global Change Biol 19, 3184-3199. 
Malyshev, A.V., Arfin Khan, M.A.S., Beierkuhnlein, C., Steinbauer, M.J., Henry, H.A.L., Jentsch, A., Dengler, J., Willner, E., Kreyling, J., 2016. Plant responses to climatic extremes: within-species variation equals among-species variation. Global Change Biol 22, 449-464.

Manion, P.D., 1991. Tree Disease Concepts. Prentice Hall.

Monserud, R.A., 1976. Simulation of Forest Tree Mortality. Forest Science 22, 438-444.

Morecroft, M.D., Roberts, J.M., 1999. Photosynthesis and stomatal conductance of mature canopy Oak (Quercus robur) and Sycamore (Acer pseudoplatanus) trees throughout the growing season. Funct Ecol 13, 332-342.

Morin, X., Chuine, I., 2014. Will tree species experience increased frost damage due to climate change because of changes in leaf phenology? Canadian Journal of Forest Research $44,1555-1565$.

Oberhuber, W., Kofler, W., Pfeifer, K., Seeber, A., Gruber, A., Wieser, G., 2008. Long-term changes in tree-ring - climate relationships at Mt. Patscherkofel (Tyrol, Austria) since the mid 1980s. Trees 22, 31-40.

Panayotov, M., Kulakowski, D., Tsvetanov, N., Krumm, F., Barbeito, I., Bebi, P., 2016. Climate extremes during high competition contribute to mortality in unmanaged self-thinning Norway spruce stands in Bulgaria. Forest Ecol Manag 369, 74-88.

Perry, T.O., 1971. Dormancy of Trees in Winter. Science 171, 29-36.

R Core Team, 2015. R: A language and environment for statistical computing. In. $\mathrm{R}$ Foundation for Statistical Computing, Vienna, Austria. http://www.R-project.org/.

Rigling, A., Eilmann, B., Koechli, R., Dobbertin, M., 2010. Mistletoe-induced crown degradation in Scots pine in a xeric environment. Tree Physiol. 30, 845-852. 
Rixen, C., Dawes, M.A., Wipf, S., Hagedorn, F., 2012. Evidence of enhanced freezing damage in treeline plants during six years of $\mathrm{CO} 2$ enrichment and soil warming. Oikos 121 , $1532-1543$.

Rohner, B., 2008. Trockenheitseffekte auf Wachstum und Mortalität der Waldföhren im Pfynwald, Wallis. In. ETH, Zürich, p. 85.

Rohner, B., Bugmann, H., Bigler, C., 2013. Estimating the age-diameter relationship of oak species in Switzerland using nonlinear mixed-effects models. Eur J Forest Res 132, 751-764.

Sala, A., Piper, F., Hoch, G., 2010. Physiological mechanisms of drought-induced tree mortality are far from being resolved. New Phytol 186, 274-281.

Sánchez-Salguero, R., Linares, J.C., Camarero, J.J., Madrigal-González, J., Hevia, A., Sánchez-Miranda, Á., Ballesteros-Cánovas, J.A., Alfaro-Sánchez, R., García-Cervigón, A.I., Bigler, C., Rigling, A., 2015. Disentangling the effects of competition and climate on individual tree growth: A retrospective and dynamic approach in Scots pine. Forest Ecol Manag 358, 12-25.

Scharnweber, T., Manthey, M., Criegee, C., Bauwe, A., Schroder, C., Wilmking, M., 2011. Drought matters - Declining precipitation influences growth of Fagus sylvatica L. and Quercus robur L. in north-eastern Germany. Forest Ecol Manag 262, 947-961.

Scheifinger, H., Menzel, A., Koch, E., Peter, C., 2003. Trends of spring time frost events and phenological dates in Central Europe. Theor Appl Climatol 74, 41-51.

Schweingruber, F.H., 1996. Tree rings and environment: Dendroecology. Haupt, Berne. 
Thiel, D., Kreyling, J., Backhaus, S., Beierkuhnlein, C., Buhk, C., Egen, K., Huber, G., Konnert, M., Nagy, L., Jentsch, A., 2014. Different reactions of central and marginal provenances of Fagus sylvatica to experimental drought. Eur J Forest Res 133, 247-260.

Thornthwaite, C.W., 1948. An approach toward a rational classification of climate. Geogr Rev 38, 55-94.

Thornton, P.E., Running, S.W., White, M.A., 1997. Generating surfaces of daily meteorological variables over large regions of complex terrain. J Hydrol 190, 214-251.

van der Maaten-Theunissen, M., Kahle, H.P., van der Maaten, E., 2013. Drought sensitivity of Norway spruce is higher than that of silver fir along an altitudinal gradient in southwestern Germany. Ann Forest Sci 70, 185-193.

van Mantgem, P.J., Stephenson, N.L., Byrne, J.C., Daniels, L.D., Franklin, J.F., Fule, P.Z., Harmon, M.E., Larson, A.J., Smith, J.M., Taylor, A.H., Veblen, T.T., 2009. Widespread Increase of Tree Mortality Rates in the Western United States. Science 323, 521-524.

Vanoni, M., Bugmann, H., Nötzli, M., Bigler, C., 2016. Quantifying the effects of drought on abrupt growth decreases of major tree species in Switzerland. Ecology and Evolution 6, 35553570.

Vicente-Serrano, S.M., Beguería, S., López-Moreno, J.I., 2010. A multiscalar drought index sensitive to global warming: The Standardized Precipitation Evapotranspiration Index. Journal of Climate 23, 1696-1718.

Vitasse, Y., Delzon, S., Dufrêne, E., Pontailler, J.-Y., Louvet, J.-M., Kremer, A., Michalet, R., 2009. Leaf phenology sensitivity to temperature in European trees: Do within-species populations exhibit similar responses? Agr Forest Meteorol 149, 735-744. 
Wermelinger, B., Rigling, A., Schneider Mathis, D., Dobbertin, M., 2008. Assessing the role of bark- and wood-boring insects in the decline of Scots pine (Pinus sylvestris) in the Swiss Rhone valley. Ecol Entomol 33, 239-249.

Zang, C., Hartl-Meier, C., Dittmar, C., Rothe, A., Menzel, A., 2014. Patterns of drought tolerance in major European temperate forest trees: climatic drivers and levels of variability. Global Change Biol 20, 3767-3779.

Zeileis, A., Kleiber, C., Kramer, W., Hornik, K., 2003. Testing and dating of structural changes in practice. Comput Stat Data An 44, 109-123.

Zeileis, A., Leisch, F., Hornik, K., Kleiber, C., 2002. strucchange: An R package for testing for structural change in linear regression models. J Stat Softw 7, 1-38. 